\title{
Decomposition and Temperature Sensitivity of Fine Root and Leaf Litter of 43 Mediterranean Species
}

\author{
Giuliano Bonanomi \\ University of Naples Federico II \\ Mohamed Idbella \\ University of Naples Federico II \\ Maurizio Zotti \\ University of Naples Federico II \\ Lucia Santorufo ( $\square$ lucia.santorufo@unina.it ) \\ University of Naples Federico II https://orcid.org/0000-0002-3409-0273 \\ Riccardo Motti \\ University of Naples Federico II \\ Giulia Maisto \\ University of Naples Federico II \\ Anna De Marco \\ University of Naples Federico II
}

\section{Research Article}

Keywords:

Posted Date: February 23rd, 2021

DOI: https://doi.org/10.21203/rs.3.rs-237069/v1

License: (c) (i) This work is licensed under a Creative Commons Attribution 4.0 International License.

Read Full License 


\section{Abstract}

\section{Aims:}

Data on the decomposition of fine roots are scarce for the Mediterranean basin. This work aims to compare chemical traits, decomposition rate, and temperature sensitivity (Q10) for root and leaf litter of 43 Mediterranean species.

\section{Methods:}

We carried out a two-years litterbag decomposition experiment using 43 fine roots litter and leaf litter types incubated in laboratory conditions at three different temperatures, i.e. $4^{\circ} \mathrm{C}, 14^{\circ} \mathrm{C}$, and $24^{\circ} \mathrm{C}$. Litter was characterized for carbon $(C)$, nitrogen $(N)$, lignin and cellulose concentration, $C / N$, and lignin/ $N$ ratios.

\section{Results:}

Fine root litter had lower $\mathrm{N}$ content but higher lignin concentration, lignin/ $\mathrm{N}$, and $\mathrm{C} / \mathrm{N}$ ratios compared to leaf litter. The decay rate of fine root litter was slower than leaf litter. For both tissues, the decay rate was negatively associated with lignin concentration, lignin/ $\mathrm{N}$, and $\mathrm{C} / \mathrm{N}$ ratios but positively with $\mathrm{N}$ concentration. Q10 was higher for fine root than leaf litter, with a positive correlation with lignin while negative with $\mathrm{N}$ concentration.

\section{Conclusions:}

Our findings demonstrate a higher Q10 accompanied by a slower decomposition rate of fine root litter compared to leaf litter in Mediterranean ecosystems. These results must be considered in modeling organic $\mathrm{C}$ at the ecosystem scale.

\section{Introduction}

Litter decomposition is a key process for biogeochemical cycles in terrestrial ecosystems. Decomposition controls the build-up of soil organic carbon (C) stock and the dynamics of major nutrients (Berg and McClaugherty 2014), thus affecting the plant diversity and productivity along with associated microbial communities (Purahong et al. 2016). At both global and regional scales, climate, i.e. temperature and moisture, is the main factor controlling the rate of litter decomposition (Aerts 1997). However, at a finer ecosystem scale, the chemical traits of decomposing plant tissue become more important compared to climatic factors (Cornwell et al. 2008). 
In general terms, the relationships between litter decomposition and temperature are fairly well established in the literature (e.g. Meentemeyer 1978; Hobbie 1996), with decomposition rates increasing in parallel with temperatures. However, the magnitude of temperature sensitivity of decomposing litter is still a debated issue, with contrasting results about the relationship between sensitivity and substrate recalcitrance (Hartley and Ineson 2008; Giardina and Ryan 2000). Theoretical and empirical evidence suggests that temperature sensitivity increases with substrate recalcitrance (Davidson and Janssens 2006; Hartley and Ineson 2008) i.e. litter with slow mass-loss is expected to increase its decay rate with rising temperature more compared to an already rapidly decomposing plant tissue. In this context, no studies have explicitly investigated the effect of temperature on mass loss of fine roots.

Fine roots (diameter $<2 \mathrm{~mm}$ ) represent a substantial fraction of ecosystem C pool and, because of their rapid turnover, account for about $14-27 \%$ of net primary productivity (McCormack et al. 2015). Freschet et al. (2013) estimated that fine root decomposition contributes to 33\% of whole litter inputs in forest ecosystems and $\sim 48 \%$ in grasslands. However, fine root usually decomposes at a slower rate than leaves and, thus, provides a disproportionate contribution to soil $\mathrm{C}$ storage compared to leaf litter (Clemmensen et al. 2013; Sun et al. 2018). The slow decay rate of fine root litter can be related to its relatively low nitrogen $(\mathrm{N})$ content coupled with larger lignin content compared to leaf litter (Zhang et al. 2008). N availability may limit litter decomposition when the $\mathrm{C} / \mathrm{N}$ ratio lies above the threshold of $\sim 30-35$ (Taylor et al. 1989). The very low initial $\mathrm{N}$ content of some plant tissues like wood debris and coarse roots (Bradford et al. 2014) can, indeed, induce a microbial $\mathrm{N}$ limitation that slows down the decomposition rate. In this regard, the first global analysis of species-specific fine root decomposition rates (Silver and Miya 2001) recorded a strong negative effect of the $\mathrm{C} / \mathrm{N}$ ratio and a positive effect of calcium (Ca). A recent meta-analysis (See et al. 2019) confirmed the positive effects of $\mathrm{N}$ concentrations and the negative effects of lignin concentration on decomposition rates of fine root litters, while the positive effect of $\mathrm{Ca}$ was not confirmed. In addition to chemical traits, the type of mycorrhizal association, i.e. ectomycorrhizal, ericoid or arbuscular (AM), may affect decomposition but their effect has not yet been fully explored (Beidler and Pritchard 2017). For instance, the presence of the ectomycorrhizal fungal mantle could contribute to the slow decomposition of woody roots (Langley et al. 2006; Sun et al. 2018).

Although the number of published studies concerning fine root decomposition has substantially increased over the last two decades (See et al. 2019), fine root decay is still poorly understood compared to leaf litter. Systematic studies comparing leaf and root decomposition have been carried out in several ecosystems, including temperate forests (Hobbie et al. 2010; Freschet et al. 2012; Jo et al. 2016; Sun et al. 2018), tropical forest (Ostertag and Hobbie 1999; Cusack et al. 2009; Wang et al. 2010), and temperate grasslands (Vivanco and Austin 2006). For Mediterranean ecosystems, however, the study of Birouste et al. (2012) was the only one that compared the decomposition rate of fine root and leaf for 18 herbaceous species. Nonetheless, no studies are available for Mediterranean shrubs and trees. In this context, this work aimed to compare chemical traits, decomposition rate, and temperature sensitivity (Q10) for root and leaf litter of 43 Mediterranean species. We carried out a two-years litterbag decomposition experiment, in which the temperature sensitivity was assessed by incubating litterbags at three temperatures, i.e. $4^{\circ} \mathrm{C}, 14^{\circ} \mathrm{C}$, and $24^{\circ} \mathrm{C}$. Leaf litter and fine roots were characterized for carbon, nitrogen 
$(\mathrm{N})$, lignin, cellulose content, $\mathrm{C} / \mathrm{N}$, and lignin/ $\mathrm{N}$ ratios. The specific targets of this work were: (i) to describe leaf litter and fine root features based on chemical traits, (ii) to assess the decomposition rate of 43 leaf litter and fine root types, (iii) to explore the relationships between litter chemical traits and the decay rate, and, (iv) to assess temperature sensitivity of leaf and fine root litter and their link along with tissue chemical traits. Based on the above considerations, three main hypotheses were tested: (1) decay rate of the fine root litter would be slower compared to leaf litter; (2) decay rate would be negatively correlated with lignin content and positively correlated with $\mathrm{N}$ concentration; (3) temperature sensitivity would be higher for fine root than leaf litter.

\section{Materials And Methods}

\subsection{Leaf litter and fine root collection}

Forty-three species common in the Mediterranean basin were selected belonging to different growth forms (Supplementary Table S1). The species list includes native and invasive plants with nine deciduous woody (Acer cappadocicum subsp. Iobelii, Broussonetia papyrifera, Castanea satvia, Celtis australis, Fagus sylvatica, Fraxinus ornus, Ostrya carpinifolia, Populus nigra and Salix purpurea), four evergreen woody (Laurus nobilis, Myrtus communis, Pistacia lentiscus and Quercus ilex), two N-fixing woody (Emerus major and Spartium junceum), nineteen forbs (Acanthus mollis, Alcea rosea, Amaranthus retroflexus, Arum italicum, Chenopodium album, Conyza canadensis, Dittrichia viscosa, Foeniculum vulgare, Medicago sativa, Oxalis pes-caprae, Papaver rhoeas, Parietaria judaica, Plantago lanceolata, Smyrnium olusatrum, Solanum nigrum, Tussilago farfara, Typha latifolia, Urtica dioicai and Xanthium italicum), four grass (Arundo donax, Hyparrhenia hirta, Heteropogon contortus and Sorghum halepense), three sedges (Carex pendula, Juncus effusus and Scirpus holoschoenus), and two vines (Hedera helix and Rubus ulmifolius). The selected species, representing 28 taxonomic families, are expected to cover a wide range of leaf litter and fine root chemical traits.

Plant litter materials were sampled across grasslands, shrublands, and woodlands located in the Campania Region, Southern Italy. Freshly abscised leaves of each species were collected from plants ( $N$ $=10$ ) randomly selected at the sampling sites. Fine roots with a diameter $<2 \mathrm{~mm}$ were collected from the top of the soil $(20 \mathrm{~cm})$. Within the sampling, a mixture of first- to third-order roots, were collected, allowing the exclusion of secondary structural roots (Jo et al. 2016). Herbaceous individuals were completely excavated using a trowel while, for woody species, roots were excavated and progressively tracked until the base of the plants to be certain of the species identity. Roots samples were washed with distilled water to remove all soil particles. After collection, leaf litter and fine root were air-dried in a ventilated chamber at $20^{\circ} \mathrm{C}$ for 30 days until reaching a constant weight and then stored at room temperature in paper bags.

\subsection{Decomposition experiment}

Plant tissue decomposition in field conditions is hierarchically controlled by litter chemistry and environmental conditions, i.e. water availability and temperature. In this study, we decomposed leaf and 
root under laboratory conditions to focus on the importance of litter chemistry on decay rate and reduce the influence of local climatic factors, e.g. fluctuation in water availability and temperature. To assess the relationship between litter chemistry and temperature sensitivity, leaves and fine roots were decomposed at three temperatures, i.e. $4^{\circ} \mathrm{C}, 14^{\circ} \mathrm{C}$, and $24^{\circ} \mathrm{C}$ that represent winter, spring/autumn, and summer conditions in many places along the Mediterranean basin.

The decomposition experiment was carried out accordingly to the litterbag method (Berg and McClaugherty 2014). Litterbags $(10 \times 10 \mathrm{~cm}$, mesh size $1 \mathrm{~mm})$ were filled with $2 \mathrm{~g}$ of leaf litter and fine root for every 43 species. Litterbags were placed, under laboratory conditions, over trays filled with soil collected from the site where most of the selected species naturally coexist (Cicerale $40^{\circ} 19^{\prime} \mathrm{N} 15^{\circ} 07^{\prime} \mathrm{E}$, $186 \mathrm{~m}$ a.s.I.). The soil is sandy loam and its specific properties are reported in Supplementary Table S2.

The microcosms were placed in a growth chamber at three temperatures, i.e. $4^{\circ} \mathrm{C}, 14^{\circ} \mathrm{C}$, and $24^{\circ} \mathrm{C}$. Microcosms were watered with distilled water every three days to maintain the soil at field capacity and avoid any drought effect on decomposition. Soil field capacity was previously determined equal to $18 \%$ in volume for Cicerale soil using the methods reported in Bonanomi et al. (2017a). The entire experimental design included 86 litter types (43 leaf litters and 43 fine root litters), incubated at three temperatures with three replicates for each species. Additionally for each experimental factor six dates of retrieval from the beginning of the experiment $(10,30,90,180,360$, and 720 days) were fixed. Overall, 4,644 litterbags were prepared (86 litter types $\times 3$ temperatures $\times 6$ retrieval times $\times 3$ replicates). At each retrieval date, litterbags were collected, oven-dried $\left(30^{\circ} \mathrm{C}\right.$ until a constant weight was reached), soil debris carefully removed by brush, and then weighed to the nearest $0.001 \mathrm{~g}$.

\subsection{Chemical analyses}

Undecomposed leaf litter and fine root were ground to get a fine powder $(<1 \mathrm{~mm})$ and the chemical determination was carried out in triplicate. Total $\mathrm{C}$ and $\mathrm{N}$ content were determined by flash combustion of micro-samples ( $5 \mathrm{mg}$ ) by a CN-elemental analyzer (Flash EA2000 Thermo). Cellulose and lignin contents were determined with the method described by Gessner (2005). Briefly, cellulose was quantified as a hydrolyzable fraction after the sulphuric acid digestion (loss after treatment with $72 \% \mathrm{H}_{2} \mathrm{SO}_{4}$ for 3 hours), while lignin was determined as a nonhydrolyzable fraction (loss upon ignition after the sulphuric acid digestion). All fractions are reported as ash-free dry mass. We highlight that lignin assessed with this method does not correspond to pure lignin, but it includes several other hydrolysis-resistant organic compounds like waxes, suberin, cutin, and condensed tannins (Berg and McClaugherty 2014). C/N and lignin/ $\mathrm{N}$ ratios for each litter type were calculated.

\subsection{Data analysis}

Litter negative exponential decay constant $(K)$ was calculated according to Berg and McClaugherty (2014). The model equation was $M_{t}=M_{0} \cdot e^{-k t}$, where $M_{0}$ is the initial mass, $M_{t}$ is the mass remaining after a certain time $t$, and $k$ is the decay rate constant. 
We used general linear models (GLMs) to test main and second-order interactive effects of plant litter types (43 species), temperatures of incubation $\left(4^{\circ} \mathrm{C}, 14^{\circ} \mathrm{C}\right.$ and $24^{\circ} \mathrm{C}$ ), and decomposition times (treated as a continuous covariate) on mass remaining percentage. Percentage mass remaining data were logtransformed before applying both GLM and Tukey HSD post-hoc tests. General linear models (GLMs) was also used to assess the effect of plant litter types, temperatures of incubation, and decomposition times on litter $K$. Differences in litter chemical traits $(\mathrm{C}, \mathrm{N}$, cellulose and lignin content, $\mathrm{C} / \mathrm{N}$ and lignin/ $\mathrm{N}$ ratios $)$ and $K$ were evaluated in all cases by paired t-test $(\mathrm{P}<0.05$ and $\mathrm{P}<0.01)$. To explore the relationship between litter $K$ with chemical traits, we calculated correlation according to non-parametric Spearman correlation rank methodology to avoid the bias of correlation between variables with non-normal distribution.

The temperature sensitivity of leaf litter and fine root decomposition was estimated by calculating the Q10 value (change in the rate of mass loss given by a $10^{\circ} \mathrm{C}$ change in temperature). Pair-wise differences were statistically evaluated by paired t-test $(P<0.05$ and $P<0.01)$. The software STATISTICA 10 (StatSoft Inc., USA) and $R$ were used for statistical analyses (R Core Team, 2020).

\section{Results}

\subsection{Chemical traits of leaf litter and fine roots}

Chemistry of undecomposed leaf litter and fine root largely varied among species (Supplementary Table S3). Leaf litter had lower lignin content, lignin/ $\mathrm{N}$, and $\mathrm{C} / \mathrm{N}$ ratio (paired t-test, $P<0.01$ for all cases) compared to root (Fig. 1). On the other hand, roots showed lower $\mathrm{N}$ content compared to leaf (paired ttest, $P<0.01$ ). No significant difference was recorded concerning the $C$ (paired t-test, $P=0.14$ ) and cellulose (paired t-test, $P=0.46$ ) content of leaf and root.

$C(r=+0.59), N(r=+0.45)$, cellulose $(r=+0.47)$ and lignin concentration $(r=+0.82)$ in leaf litter and the corresponding fine roots were positively correlated. Similarly, the $\mathrm{C} / \mathrm{N}$ ratio $(r=+0.67)$ and lignin/N ratio $(r$ $=+0.79$ ) of leaf litter and the corresponding fine roots were also correlated.

\subsection{Decomposition of leaf litter and fine roots}

Leaf and root decay rate $(K)$ largely varied among species and was significantly affected by the plant species, the temperature of incubation, and incubation time (Table S4). At low temperature $\left(4^{\circ} \mathrm{C}\right), \mathrm{K}$ ranged from 0.69 (A. italicum) to 0.10 (F. sylvatica) for leaf and from 0.64 (A. mollis) to 0.02 (A. lobelii) for root (Supplementary Figure $S 1$ ). At $14^{\circ} \mathrm{C}$ of incubation, $K$ ranged from 0.92 (A. retroflexus) to 0.48 ( $L$. nobilis) for leaf and from 0.86 (A. mollis) to 0.07 (S. holoshoenus) for root (Fig. 2). At $24^{\circ} \mathrm{C}, K$ was less variable among leaf litter with 19 species having a $K>0.90$ (Supplementary Figure S2). For root, instead, only three species had $\mathrm{K}>0.90$ (P. lanceolata, $R$. ulmifolius, and $X$. italicum) with the lowest decay rate recorded for the grass $C$. hirtus and the evergreen tree $Q$. ilex ( $K=0.19$ in both cases). 
Across the 43 plant species, we found a slower mass loss for fine root litter compared to leaf litter at all incubation temperature. In detail, after two years of incubation at $4^{\circ}$, we found $35.31 \%$ and $56.57 \%$ mass remaining for leaf litter and fine roots, respectively. At $14^{\circ} \mathrm{C}$ the mass remaining was $10.01 \%$ for leaf and $37.09 \%$ for fine root, and only $2.55 \%$ of leaf mass at $24^{\circ} \mathrm{C}$, while $23.72 \%$ remained for fine root (Fig. 3a). Decay rate $(K)$ of leaf litters was faster than that of root litter at the three temperatures of incubation (paired t-test, $\mathrm{P}<0.01$ in all cases) (Fig. 3b). Overall, root decay rate $(\mathrm{K})$ exceeds that of the corresponding leaf only in 12 cases out of 129 comparisons (9.3\% of the cases) (Fig. 3c).

\subsection{Linking decay rate with woody debris traits}

Considering the chemical parameters of undecomposed tissues, the decay rate $(K)$ showed a similar response for leaf and root with a trend of positive correlation with $\mathrm{N}$ and negative with lignin and carbon content, and lignin/N ratio (Fig. 4). Notably, the strength of the correlation changed with the temperature of incubation. The correlations were highly significant at $4^{\circ} \mathrm{C}$ for lignin, $\mathrm{C} / \mathrm{N}$, lignin/ $\mathrm{N}$, and $\mathrm{N}$ but, at $14^{\circ} \mathrm{C}$ and especially $24^{\circ} \mathrm{C}$ they became weaker or even not significant. At $24^{\circ} \mathrm{C}$ the correlation between $K$ and lignin and lignin/ $\mathrm{N}$ ratio remained significant for root litter but not for leaf litter. For $\mathrm{N}$, instead, the positive correlation with $\mathrm{K}$ was significant only at $4^{\circ} \mathrm{C}$ for leaf and at $4^{\circ} \mathrm{C}$ and $14^{\circ} \mathrm{C}$ for root litter. Finally, the correlation between the $\mathrm{C} / \mathrm{N}$ ratio and $K$ was significant only for the leaf litter at $4^{\circ} \mathrm{C}$ of incubation.

\subsection{Temperature sensitivity of leaf litter and fine root litter}

Mass loss significantly increased with temperature for litter types, with $Q 10$ values (average \pm standard deviation) that were $2.36 \pm 0.32$ for leaf litter and $4.21 \pm 1.01$ for fine roots (paired t-test, $P<0.01$; Fig. 5a). Moreover, Q10 was higher for fine root than the corresponding leaf litter in 35 out of 43 cases $(81.40 \%)$ (Fig. 5b). For leaf litter, Q10 was positively correlated with $\mathrm{N}$ content and negatively with lignin and lignin/N ratio (Fig. 5c). Q10 of fine roots, instead, recorded only a highly significant negative correlation with lignin content. Finally, Q10 of both leaf litter and fine roots was negatively correlated with their decay rate (Fig. $5 d$ ).

\section{Discussion}

Our experiment, based on forty-three paired leaf litter and fine root types demonstrated that the mass loss of root is consistently lower compared to leaf. In terms of litter chemistry, fine root litters had lower $\mathrm{N}$ content but higher lignin concentration, lignin/ $\mathrm{N}$, and $\mathrm{C} / \mathrm{N}$ ratios compared to leaf litters. According to previous studies, the decay of plant tissues was negatively associated with lignin concentration, lignin/ $\mathrm{N}$, and $\mathrm{C} / \mathrm{N}$ ratios but positively with $\mathrm{N}$ concentration. Notably, $\mathrm{Q} 10$ was higher for fine root than leaf litter, and was positively correlated with lignin content and negatively with $\mathrm{N}$ concentration. The higher temperature sensitivity paired with a slower decomposition rate of the fine root litter compared to leaf litter in Mediterranean ecosystems must be considered in modeling organic $\mathrm{C}$ at the ecosystem scale.

\subsection{Leaf litter and fine root decomposition}


Fine roots of tested species decomposed at a slower rate than leaves at all incubation temperature. The decay rate of fine roots was lower than the corresponding leaf in 117 cases out of 129 comparisons ( $90.7 \%$ of the cases). In this regards, our results confirmed the assumptions from previous studies that reported a slower degradation for root litter than leaf litter (van Vuuren et al. 1993; Cusack et al. 2009; Xiong et al. 2013; Bonanomi et al. 2017b), although the opposite trend was also reported (Ostertag and Hobbie 1999). The limited mass loss suggested an important role of fine roots also for soil $C$ sequestration and $\mathrm{C}$ and $\mathrm{N}$ dynamics in Mediterranean ecosystems. The slow decay of fine roots was probably due to chemical traits, mainly to a lower $\mathrm{N}$ concentration coupled with a higher lignin content of fine root litter as compared to corresponding leaf litter. Moreover, mass loss rates were negatively correlated with lignin content, lignin/ $\mathrm{N}$ ratio but positively with $\mathrm{N}$ concentration. Correlation analysis highlighted the importance of $\mathrm{N}$ and lignin in controlling fine root decay rate and confirmed the wellestablished previous knowledge reported for both fine roots (See et al. 2019), and woody debris (Meentemeyer 1978; Weedon et al. 2009). In general terms, the low $\mathrm{N}$ concentration coupled with the high lignin content of fine root would induce an $\mathrm{N}$ limitation for decomposer microbes. $\mathrm{C} / \mathrm{N}$ ratio of all decomposing substrate that lies above the threshold of $\sim 30$ would be $N$ limited (Taylor et al. 1989), In our study only 6 leaf litter types $(13.9 \%)$ has a $\mathrm{C} / \mathrm{N}$ above 30 while 18 fine root litters $(41.8 \%)$ exceed this threshold, indicating that $\mathrm{N}$ limitation would be more important for fine root. Notably, previous studies demonstrated that microbe may require extra $\mathrm{N}$ from other sources like the underlying soil (Schimel and Hättenschwiler 2007; De Marco et al., 2008; Lummer et al. 2012; Berglund and Ågren 2012). In this regard, the present study probably underestimates the potential effect of $\mathrm{N}$ limitation because fine root litter was incubated on $\mathrm{N}$ rich soil from a woodland. In other words, fine root decomposing in nutrient-poor soils may exacerbate microbial $\mathrm{N}$ starvation and, thus, further slow their decay rate. Further studies carried out across the gradient of soil $\mathrm{N}$ availability could provide useful insights about the dynamics and impact of $\mathrm{N}$ limitation on fine root decomposition.

Our results supported the paradigm of lignin/ $\mathrm{N}$ ratio control over litter decomposition for both leaf litter and fine roots. However, our experiment carried out across an ample temperature gradient i.e. from $4^{\circ} \mathrm{C}$ to $24^{\circ} \mathrm{C}$, demonstrated that both lignin and $\mathrm{N}$ limitation are stronger at low temperature. The strong negative correlation between decay rate with lignin, lignin $/ \mathrm{N}$, and $\mathrm{C} / \mathrm{N}$ ratio recorded at $4^{\circ} \mathrm{C}$ became weaker or not significant at $24^{\circ} \mathrm{C}$. The same pattern was observed for $\mathrm{N}$ where the strong positive correlations observed at $4^{\circ} \mathrm{C}$ became not significant at $24^{\circ} \mathrm{C}$. Surprisingly, when leaf litter was incubated at $24^{\circ}$ neither lignin/ $\mathrm{N}$ ratio, $\mathrm{C} / \mathrm{N}$ ratio, nor the concentrations of lignin and $\mathrm{N}$ were correlated with decay rate. These results suggest that both lignin and $\mathrm{N}$ concentration limit decomposition more intensely at low than high temperatures. In the case of lignin, it could be hypothesized that the complex enzymatic machinery required to decompose lignin is less efficient at low temperatures (Fioretto et al., 2000; 2018). Instead, the $\mathrm{N}$ limitation in $\mathrm{N}$ poor plant tissue could be more intense at low temperature because of the reduction of exogenous $\mathrm{N}$ input derived from slower mineralization of soil organic matter than at $24^{\circ} \mathrm{C}$ (Stanford et al. 1973). In other words, at $24^{\circ} \mathrm{C}$ the rapid mineralization from the underling soil would provide a larger $\mathrm{N}$ source that could remedy the $\mathrm{N}$ limitation of $\mathrm{N}$ poor plant tissue. Overall, the increasing importance of lignin and $\mathrm{N}$ in controlling decomposition as temperature decreases deserves further studies. 
Notably, the $\mathrm{C} / \mathrm{N}$ ratio was negatively correlated with the decay rate of leaf litter, at least at low temperature, but not for fine root. Several studies criticized the $\mathrm{C} / \mathrm{N}$ ratio, debating its capability to predict leaf (Hättenschwiler et al. 2011; Cartenì et al. 2018) and fine root decomposition (Goebel et al. 2011). Instead, a recent study reported that the initial $\mathrm{C} / \mathrm{N}$ ratio achieved very high and significant correlations with the decay rate of wood debris (Bonanomi et al. 2021). We suspect that the very high $\mathrm{C} / \mathrm{N}$ ratio and wood debris with the consequent extreme $\mathrm{N}$ limitation would obscure the dependence of decomposition dynamics from this parameter; probably a more detailed description of $\mathrm{C}$ chemistry would be necessary Furthermore, for both leaf litter and fine root, the need to define C-quality to predict decay rate seemed confirmed by the negative correlation shown between the lignin/ $\mathrm{N}$ ratio and decay rate at all incubation temperatures. In this regard, our study is not in contradiction with the findings of Sun et al. (2018) where lignin content and lignin/ $\mathrm{N}$ ratio were unrelated to the decay rate of first order roots of 35 woody species. Our study used a mixture of first- to third-order roots and so cannot contribute to the debate concerning the very low decay rate of the first order roots despite their low lignin and relatively high $\mathrm{N}$ concentration (Goebel et al. 2011; Beidler and Pritchard 2017). Further studies are needed to understand the recalcitrance of thin root tissues to decomposition focusing on root chemical, anatomical traits also with the extent and the type of mycorrhizal colonization (Langley and Hungate 2006).

\subsection{Temperature sensitivity of decomposing leaf and fine root}

In this study, we found that roots increase their decay rate more than leaf as temperature rise, i.e. root decomposition is more temperature-sensitive than the corresponding leaf. This finding suggests that microbial as well as enzymatic activities, which are generally faster at higher temperatures, strongly interact with litter chemistry. Temperature sensitivity of plant litter is still a debated issue, with theoretical models and empirical evidence that suggest an increased sensitivity with substrate recalcitrance (Fierer et al. 2005; Hartley and Ineson 2008; Conant et al. 2008), although opposing evidence are available (e.g. Giardina and Ryan 2000; Liski et al., 1999). The decomposition process, like all chemical and biochemical reactions, are temperature-dependent. In this context, basic thermodynamics theory predicts that organic matter recalcitrant substrates, that usually resist decomposition, will be more sensitive to an increase in temperature (Bosatta and Ågren 1999). In detail, recalcitrant substrates require higher activation energy and, consequently, are more sensitive to temperature than labile organic matter (Davidson and Janssens 2006). According to this theory, our results based on 86 litter types demonstrate that the temperature sensitivity of decay litter decreases with increasing recalcitrance. In fact, Q10 was negatively correlated with initial $\mathrm{N}$ concentration and positively with lignin content, i.e. factors driving the decay rate. Besides, for both leaf litter and fine roots the $Q 10$ was negatively correlated with litter decay rate: i.e. temperature sensitivity increase with decreasing litter decay. Fierer et at. (2005) using 24 litter types reported that as the overall quality of the organic $\mathrm{C}$ declined, litter decomposition became more sensitive to temperature. The authors also highlighted that litter temperature sensitivity would be different from that of soil organic matter because factors like chemical and physical protection in soil (Thornley and Cannell 2001) may potentially obscure any relationship between $\mathrm{C}$ quality and $Q 10$. Thus as highlighted in a recent study (Bonanomi et al. 2017b), the temperature sensitivity of recalcitrant substrates could be obscured by $\mathrm{N}$ 
limitation, as well as by other constraints such as water scarcity, flooding, freezing, or physical and chemical protection of organic matter as previously reported.

Finally, the direct comparison of our Q10 values with others reported in the literature should be done with caution because of the different methods used. Several laboratory-based experiments made to assess litter and soil temperature sensitivity to decomposition used short-term laboratory incubations and measured respiration rate. This approach had the advantage of eliminating the confounding effects of the sample temperature history and the litter quality does not change appreciably throughout these assays (Fierer et al. 2005). Instead, longer assay times as in the litter-bag experiment may lead to an underestimation of Q10 (Burke et al. 2003).

\section{Conclusions}

The data from this comparative study based on 43 plant Mediterranean species from 28 taxonomic families demonstrate that fine root litter decomposes at a slower rate than the leaf litter from the same species. Our results further indicate that fine roots had different chemistry, being more lignified with a lower $\mathrm{N}$ concentration compared to the corresponding leaf litter. Moreover, fine root decomposition is more sensitive to temperature with an average Q10 of 4.21 compared to 2.36 of leaf litter. According to the literature, we found that $\mathrm{N}$, lignin, and lignin/ $\mathrm{N}$ ratio well predict leaf litter and fine root decay but only at low temperature, with a poor predictive power at high temperature, suggesting that $\mathrm{N}$ and lignin limitation of decomposition is important only at low temperature. In contrast to leaf litter, the large interspecific variation in fine root decomposition cannot be predicted by the well-established $\mathrm{C} / \mathrm{N}$ ratio. These findings need future integration into the predictive framework and model of biogeochemical cycling.

\section{Declarations}

Funding This research did not receive any specific grant from funding agencies in the public, commercial, or not-for-profit sectors.

Conflicts of interest/Competing interests The authors declare no conflict of interest

Availability of data and material Data available on request

Code availability Not applicable

Authors' contributions GB, MI and MZ conceived and designed the experiments; ADM, GM and LS performed the $\mathrm{C}$ and $\mathrm{N}$ analyses on litter and roots; $\mathrm{GB}, \mathrm{MI}, \mathrm{MZ}$ and $\mathrm{RM}$ performed field work and contributed to analyses; GB, MI, MZ and RM wrote the paper; LS, ADM and reviewed and edited the paper. All authors contributed to the article and approved the submitted version.

Ethics approval Not applicable 
Consent to participate Not applicable

Consent for publication Not applicable

\section{References}

Aerts R (1997) Climate, leaf litter chemistry, and leaf litter decomposition in terrestrial ecosystems: a triangular relationship. Oikos 79:439-449. https://doi.org/10.2307/3546886

Beidler KV, Pritchard SG (2017) Maintaining connectivity: understanding the role of root order and mycelial networks in fine root decomposition of woody plants. Plant Soil 420:19-36

Berg B, McClaugherty C (2014) Plant litter: Decomposition, humus formation and carbon sequestration. Springer-Verlag, Berlin

Berglund SL, Ågren GI (2012) When will litter mixtures decompose faster or slower than individual litters? A model for two litters. Oikos 121:1112-1120. https://doi.org/10.1111/j.1600-0706.2011.19787.x

Birouste M, Kazakou E, Blanchard A, Roumet C (2012) Plant traits and decomposition: are the relationships for roots comparable to those for leaves? Ann Bot 109:463-472

Bonanomi G, Cesarano G, Gaglione SA, Ippolito F, Sarker T, Rao MA (2017b) Soil fertility promotes decomposition rate of nutrient poor, but not nutrient rich litter through nitrogen transfer. Plant Soil 412:397-411

Bonanomi G, Chirico GB, Palladino M, Gaglione SA, Crispo DG, Lazzaro U, Sica B, Cesarano G, Ippolito F, Sarker TC, Rippa M, Scala F (2017a) Combined application of photo-selective mulching films and beneficial microbes affects crop yield and irrigation water productivity in intensive farming systems. Agric Water Manag 184:104-113

Bonanomi G. Zotti M, Cesarano G, Sarker TC, Saulino L, Saracino S, Idbella M, Agrelli D, D'Ascoli R, Rita A, Adamo P, Allevato E (2021) Decomposition of woody debris in Mediterranean ecosystems: the role of wood chemical and anatomical traits. Plant Soil, In press

Bosatta E, Ågren GI (1999) Soil organic matter quality interpreted thermodynamically. Soil Biol Biochem 31:1889-1891

Bradford MA, Warren li RJ, Baldrian P, Crowther TW, Maynard DS, Oldfield EE, Wieder WR, Wood SA, King JR (2014) Climate fails to predict wood decomposition at regional scales. Nat Clim Change 4:625. https://doi.org/10.1038/nclimate2251

Burke IC, Kaye JP, Bird SP, Hall SA, McCulley RL, Sommerville GL (2003) Evaluating and testing models of terrestrial biogeochemistry: the role of temperature in controlling decomposition. In: Canham C, Cole J, Lauenroth W (eds) Models in ecosystem science. Princeton University Press, Princeton, pp 225-253 
Cartenì F, Sarker TC, Bonanomi G, Cesarano G, Esposito A, Incerti G, Mazzoleni S, Lanzotti V, Giannino F (2018) Linking plant phytochemistry to soil processes and functions: the usefulness of $13 \mathrm{C} \mathrm{NMR}$ spectroscopy. Phytochem Reviews 17:815-832. https://doi.org/10.1007/s11101-018-9560-6

Clemmensen KE, Bahr A, Ovaskainen O, Dahlberg A, Ekblad A, Wallander H, Stenlid J, Finlay RD, Wardle DA, Lindahl BD (2013) Roots and associated fungi drive long-term carbon sequestration in boreal forest. Science 339:1615-1618

Conant RT, Drijber RA, Haddix ML, Parton WJ, Paul EA, Plante AF, Steinweg JM (2008) Sensitivity of organic matter decomposition to warming varies with its quality. Glob Change Biol 14(4):868-877

Cornwell WK, Cornelissen JH, Amatangelo K, Dorrepaal E, Eviner VT, Godoy O, Hobbie SE, Hoorens B, Kurokawa $\mathrm{H}$, Pérez-Harguindeguy $\mathrm{N}$ et al (2008) Plant species traits are the predominant control on litter decomposition rates within biomes worldwide. Ecol Letters 11:1065-1071.

https://doi.org/10.1111/j.1461-0248.2008.01219.x

Cusack DF, Chou WW, Yang WH, Harmon ME, Silver WL (2009) Controls on long-term root and leaf litter decomposition in neotropical forests. Glob Change Biol 15(5):1339-1355

Davidson EA, Janssens IA (2006) Temperature sensitivity of soil carbon decomposition and feedbacks to climatic change. Nature 440:165-173

De Marco A, Meola A, Esposito F, Virzo De Santo A (2008) Productivity and modifications of ecosystem processes in gaps of a low Macchia in southern Italy. Web Ecol 8:55-66

Fierer N, Craine JM, McLauchlan K, Schimel JP (2005) Litter quality and the temperature sensitivity of decomposition. Ecology 86(2):320-326

Fioretto A, Papa S, Curcio E, Sorrentino G, Fuggi A (2000) Enzyme dynamics on decomposing leaf litter of Cistus incanus and Myrtus communis in a Mediterranean ecosystem. Soil Biol Biochem 32:1847-1855

Fioretto A, Innangi M, De Marco A, Menta C, Papa S, Pellegrino A, Virzo De Santo A (2018) Discriminating between Seasonal and Chemical Variation in Extracellular Enzyme Activities within Two Italian Beech Forests by Means of Multilevel Models. Forests 9:219

Freschet GT, Aerts R, Cornelissen JH (2012) A plant economics spectrum of litter decomposability. Funct Ecol 26(1):56-65

Freschet GT, Cornwell WK, Wardle DA et al (2013) Linking litter decomposition of above- and belowground organs to plant-soil feedbacks worldwide. JEcol 101:943-952

Gessner O (2005) Proximate lignin and cellulose. In: Graca MAS, Bärlocher F, Gessner MO (eds) Methods to Study Litter Decomposition. A Practical Guide. Springer Verlag, Dordrecht, pp 115-120 
Giardina CP, Ryan M (2000) Evidence that decomposition rates of organic carbon in mineral soil do not vary with temperature. Nature 404:858-861

Goebel M, Hobbie SE, Bulaj B, Zadworny M, Archibald DD, Oleksyn J, Reich PB, Eissenstat DM (2011) Decomposition of the finest root branching orders: linking belowground dynamics to fine-root function and structure. Ecol Monog 81:89-102. https://doi.org/10.1890/09-2390.1

Hartley IP, Ineson P (2008) Substrate quality and the temperature sensitivity of soil organic matter decomposition. Soil Biol Biochem 40:1567-1574

Hättenschwiler S, Coq S, Barantal S, Handa IT (2011) Leaf traits and decomposition in tropical rainforests: revisiting some commonly held views and towards a new hypothesis. New Phytol 189(4):950-965

Hobbie SE, Oleksyn J, Eissenstat DM, Reich PB (2010) Fine root decomposition rates do not mirror those of leaf litter among temperate tree species. Oecologia 162(2):505-513

Jo I, Fridley JD, Frank DA (2016) More of the same? In situ leaf and root decomposition rates do not vary between 80 native and nonnative deciduous forest species. New Phytol 209(1):115-122

Langley JA, Chapman SK, Hungate BA (2006) Ectomycorrhizal colonization slows root decomposition: the post-mortem fungal legacy. Ecol Lett 9:955-959

Lenth R (2020) Emmeans: Estimated Marginal Means, aka Least-Squares Means. R package version 1.4.7. https://CRAN.R-project.org/package $=$ emmeans

Liski J, Ilvesniemi H, Makela A, Westman CJ (1999) $\mathrm{CO}_{2}$ emissions from soil in response to climatic warming are overestimated-the decomposition of old soil organic matter is tolerant of temperature. Ambio 28:171-174

Lummer D, Scheu S, Butenschoen O (2012) Connecting litter quality, microbial community and nitrogen transfer mechanisms in decomposing litter mixtures. Oikos 121:1649-1655.

https://doi.org/10.1111/j.1600-0706.2011.20073.x

McCormack ML, Dickie IA, Eissenstat DM et al (2015a) Redefining fine-roots improves understanding of below-ground contributions to terrestrial biosphere processes. New Phytol 207:505-518

Ostertag R, Hobbie SE (1999) Early stages of root and leaf decomposition in Hawaiian forests: effects of nutrient availability. Oecologia 121(4):564-573

Purahong W, Wubet T, Lentendu G, Schloter M, Pecyna MJ, Kapturska D, Hofrichter M, Krüger D, Buscot F (2016) Life in leaf litter: novel insights into community dynamics of bacteria and fungi during litter decomposition. Mol Ecol 25:4059-4074 
R Development Core Team (2017) R: A language and environment for statistical computing. Vienna, A: R Foundation for Statistical Computing. RC Team, Vienna

Schimel JP, Hättenschwiler S (2007) Nitrogen transfer between decomposing leaves of different N status. Soil Biol Biochem 39:1428-1436. https://doi.org/10.1016/j.soilbio.2006.12.037

See CR, Luke McCormack M, Hobbie SE, Flores-Moreno H, Silver WL, Kennedy PG (2019) Global patterns in fine root decomposition: climate, chemistry, mycorrhizal association and woodiness. Ecol Lett 22(6):946-953

Silver WL, Miya R (2001) Global patterns in root decomposition: comparisons of climate and litter quality effects. Oecologia 129:407-419

Stanford G, Frere MH, Schwaninger DH (1973) Temperature coefficient of soil nitrogen mineralization. Soil Sci 115(4):321-323

Sun T, Hobbie SE, Berg B, Zhang H, Wang Q, Wang Z, Hättenschwiler S (2018) Contrasting dynamics and trait controls in first-order root compared with leaf litter decomposition. PNAS 115(41):10392-10397

Taylor BR, Parkinson D, Parsons WF (1989) Nitrogen and lignin content as predictors of litter decay rates: a microcosm test. Ecology 70:97-104. https://doi.org/10.2307/1938416

Thornley JHM, Cannell MGR (2001) Soil carbon storage response to temperature: an hypothesis. Ann Bot 87:591-598

Vivanco L, Austin AT (2006) Intrinsic effects of species on leaf litter and root decomposition: a comparison of temperate grasses from North and South America. Oecologia 150(1):97-107

Vuuren MV, Berendse F, Visser WD (1993) Species and site differences in the decomposition of litters and roots from wet heathlands. Can J Bot 71(1):167-173

Wang H, Liu S, Mo J (2010) Correlation between leaf litter and fine root decomposition among subtropical tree species. Plant Soil 335(1-2):289-298

Weedon JT, Cornwell WK, Cornelissen JH, Zanne AE, Coomes DA (2009) Global meta-analysis of wood decomposition rates: a role for trait variation among tree species? Ecol Lett 12:45-56. https://doi.org/10.1111/j.1461-0248.2008.01259.x

Xiong Y, Fan P, Fu S, Zeng H, Guo D (2013) Slow decomposition and limited nitrogen release by lower order roots in eight Chinese temperate and subtropical trees. Plant Soil 363(1-2):19-31

Zhang DQ, Hui DF, Luo YQ, Zhou GY (2008) Rates of litter decomposition in terrestrial ecosystems: global patterns and controlling factors. J Plant Ecol 1:85-93 
Figures
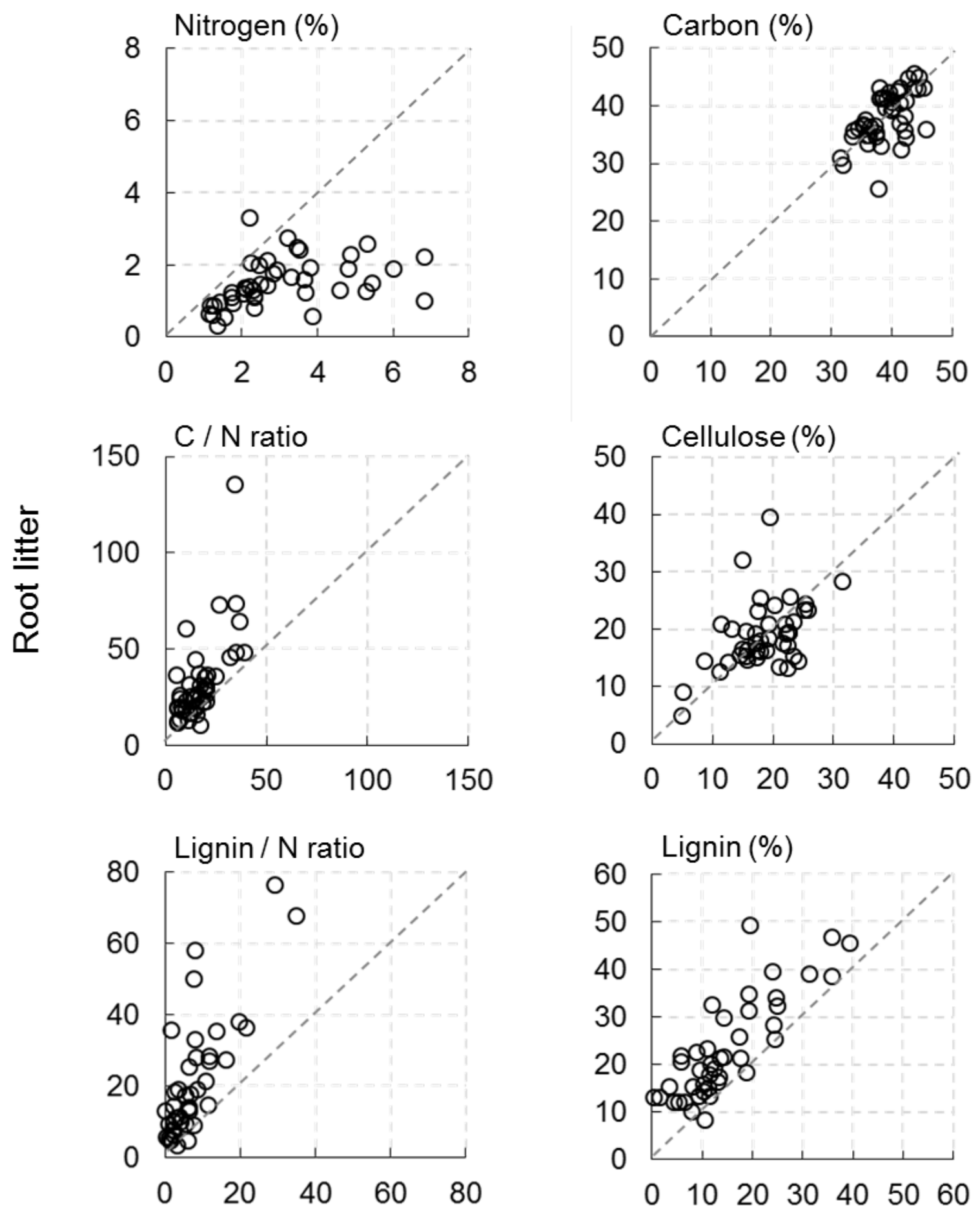

\section{Leaf litter}

Figure 1

Leaf litter had lower lignin content, lignin/ $\mathrm{N}$, and $\mathrm{C} / \mathrm{N}$ ratio (paired t-test, $\mathrm{P}<0.01$ for all cases) compared to root 


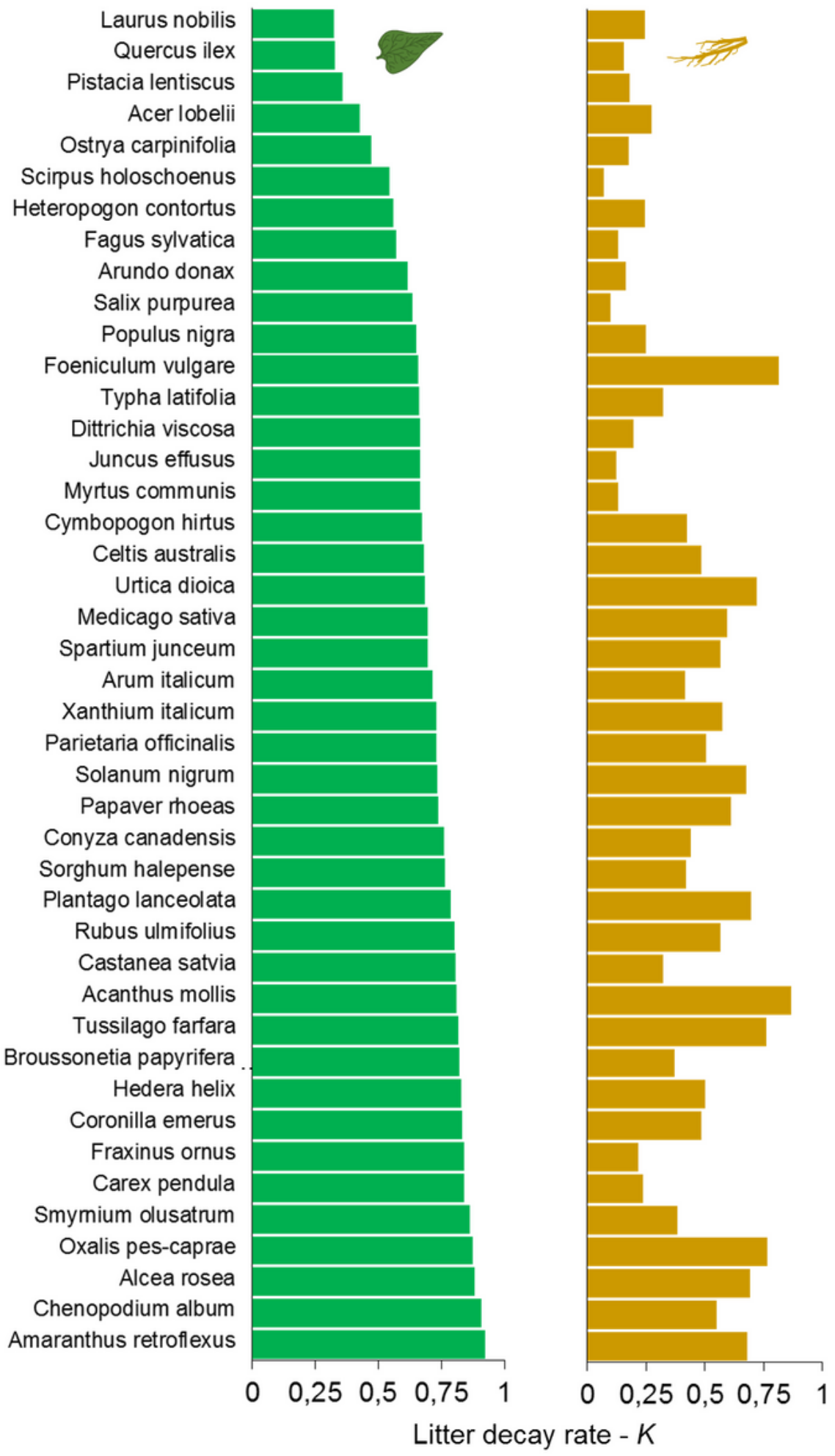

Figure 2

At $14^{\circ} \mathrm{C}$ of incubation, $\mathrm{K}$ ranged from 0.92 (A. retroflexus) to 0.48 (L. nobilis) for leaf and from 0.86 (A. mollis) to 0.07 (S. holoshoenus) for root 
(A)
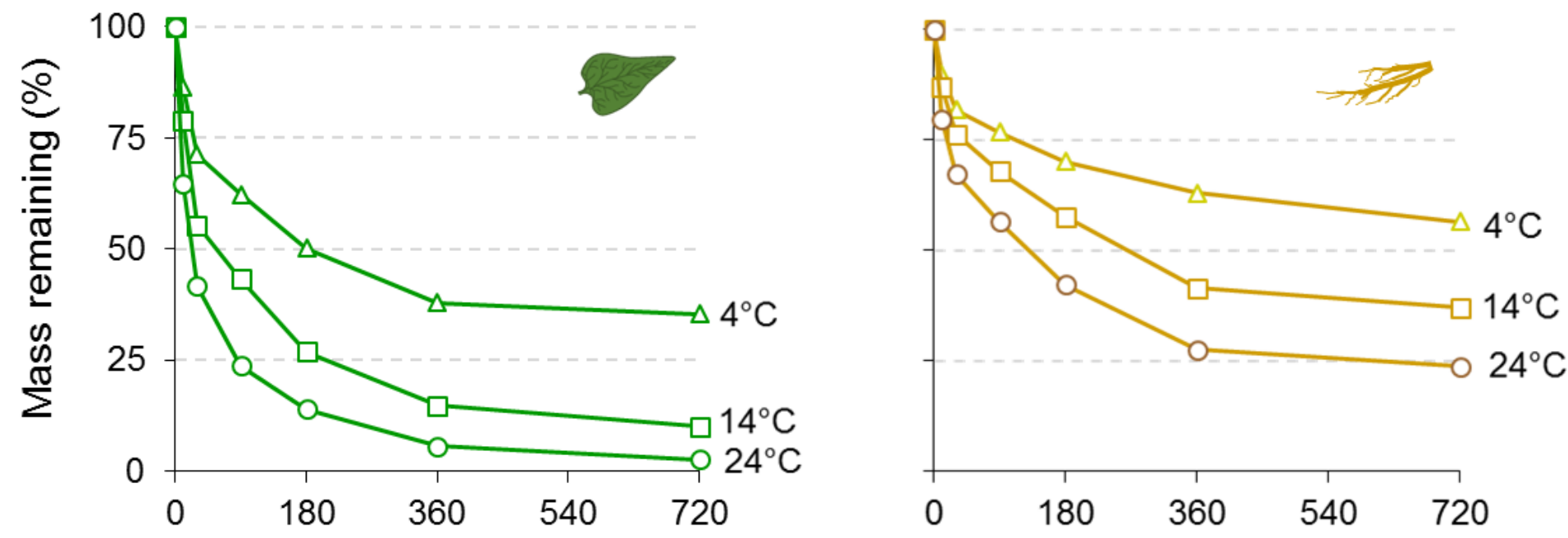

Decomposition time (days)
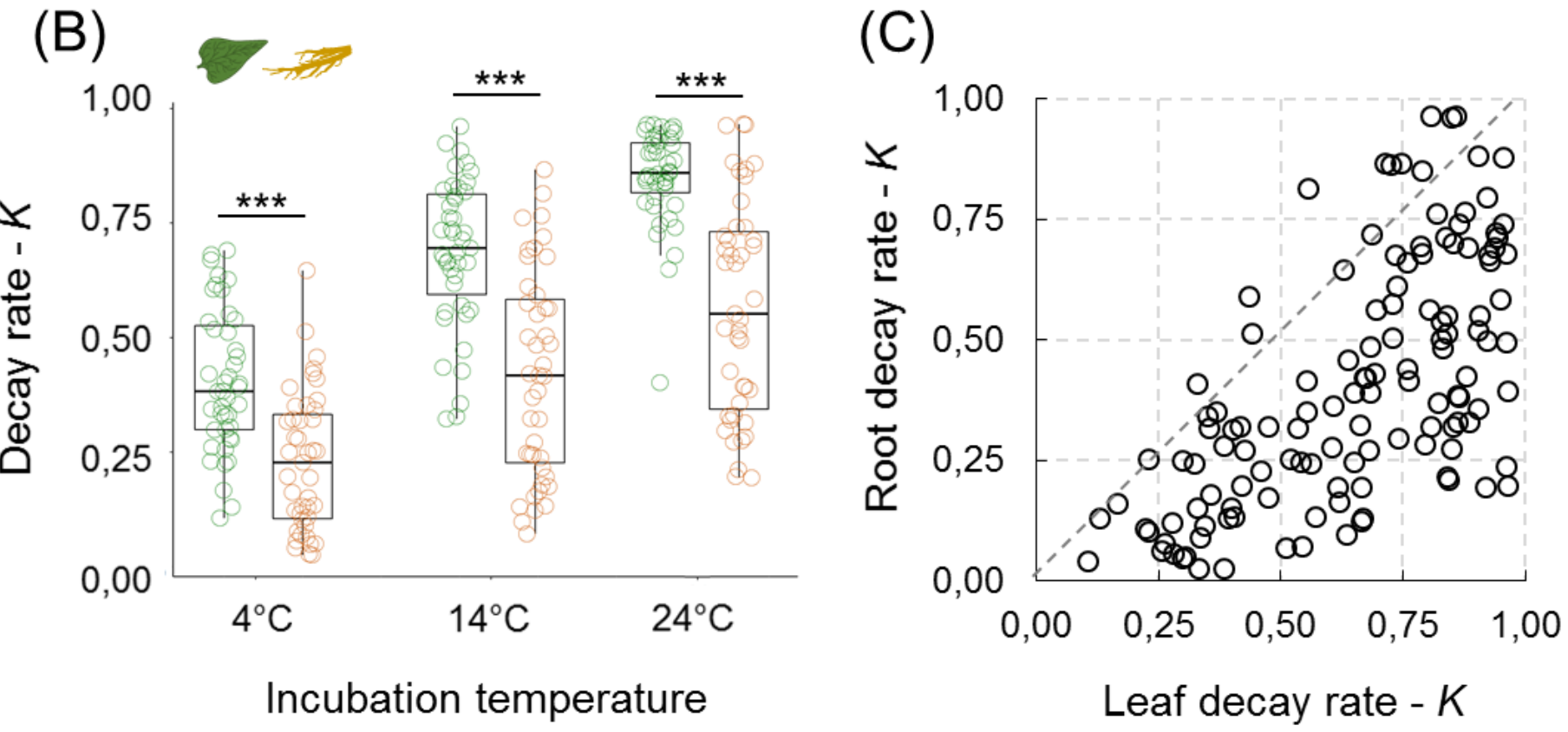

Figure 3

At $14^{\circ} \mathrm{C}$ the mass remaining was $10.01 \%$ for leaf and $37.09 \%$ for fine root, and only $2.55 \%$ of leaf mass at $24^{\circ} \mathrm{C}$, while $23.72 \%$ remained for fine root (Figure 3a). Decay rate $(\mathrm{K})$ of leaf litters was faster than that of root litter at the three temperatures of incubation (paired t-test, $\mathrm{P}<0.01$ in all cases) (Figure $3 b$ ). Overall, root decay rate $(K)$ exceeds that of the corresponding leaf only in 12 cases out of 129 comparisons ( $9.3 \%$ of the cases) (Figure 3c). 


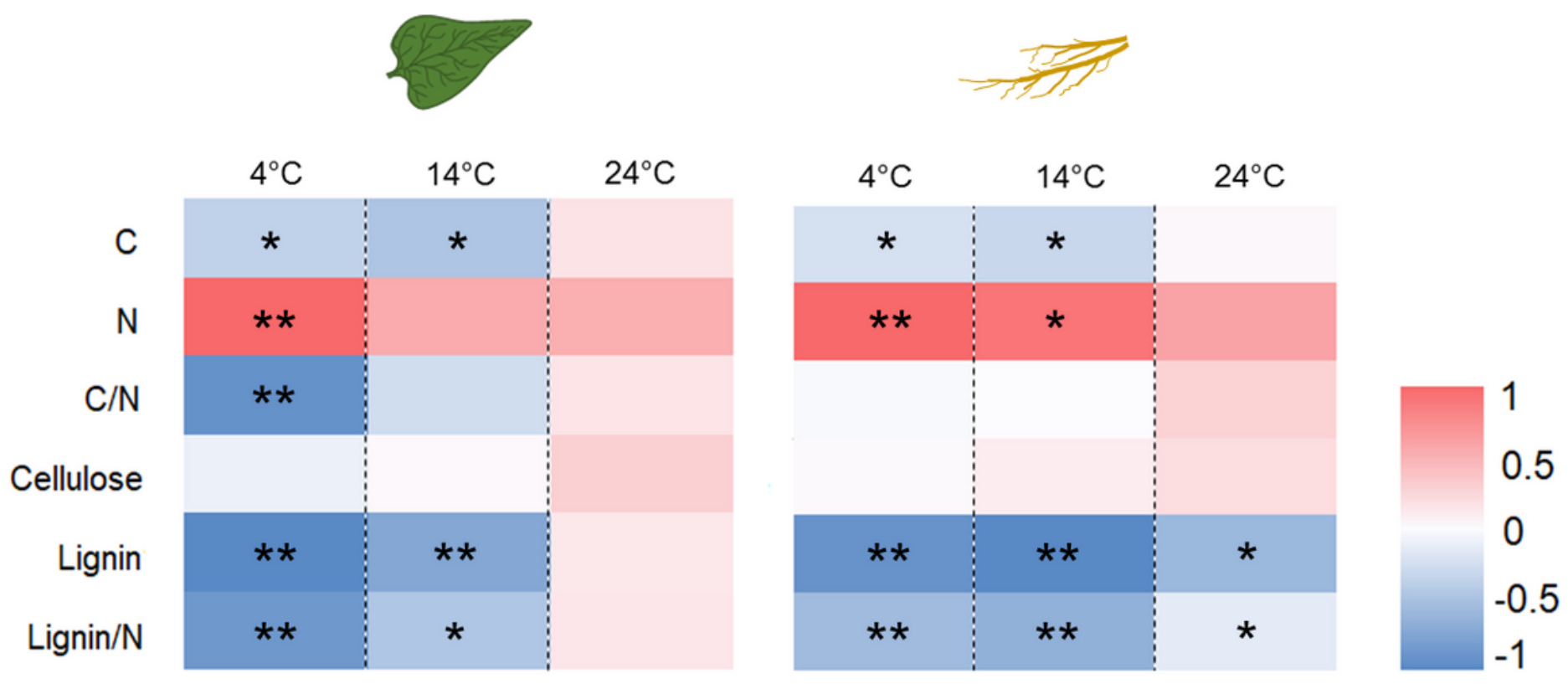

Figure 4

Considering the chemical parameters of undecomposed tissues, the decay rate $(\mathrm{K})$ showed a similar response for leaf and root with a trend of positive correlation with $\mathrm{N}$ and negative with lignin and carbon content, and lignin/ $\mathrm{N}$ ratio 
(A)

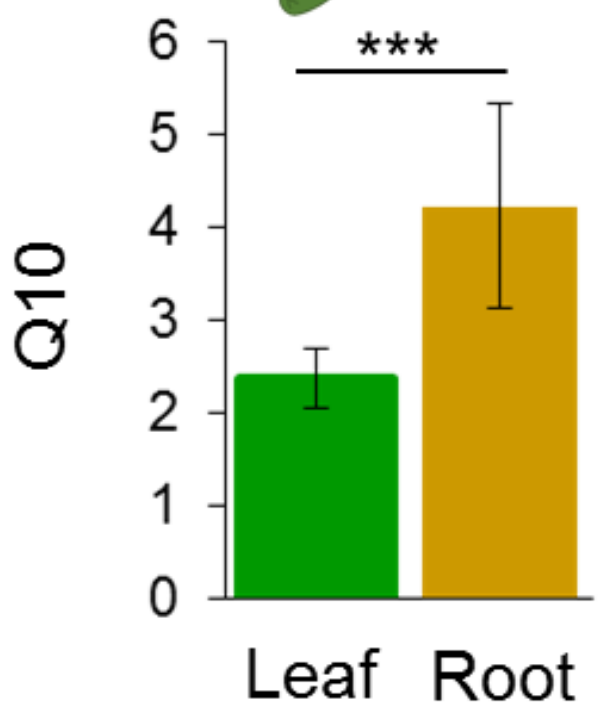

(C)
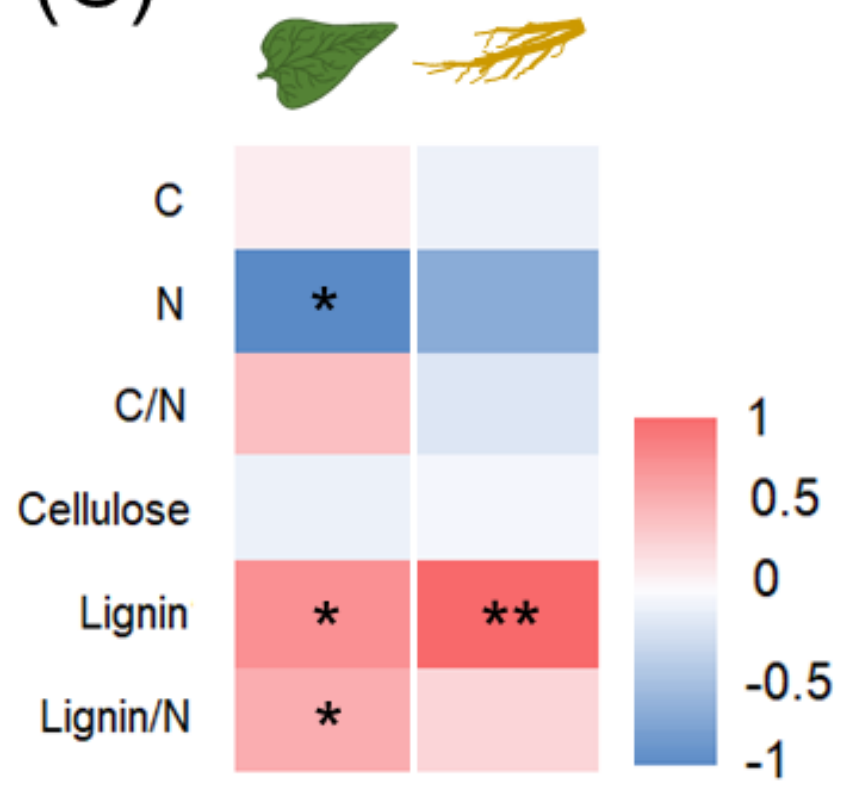

(B)

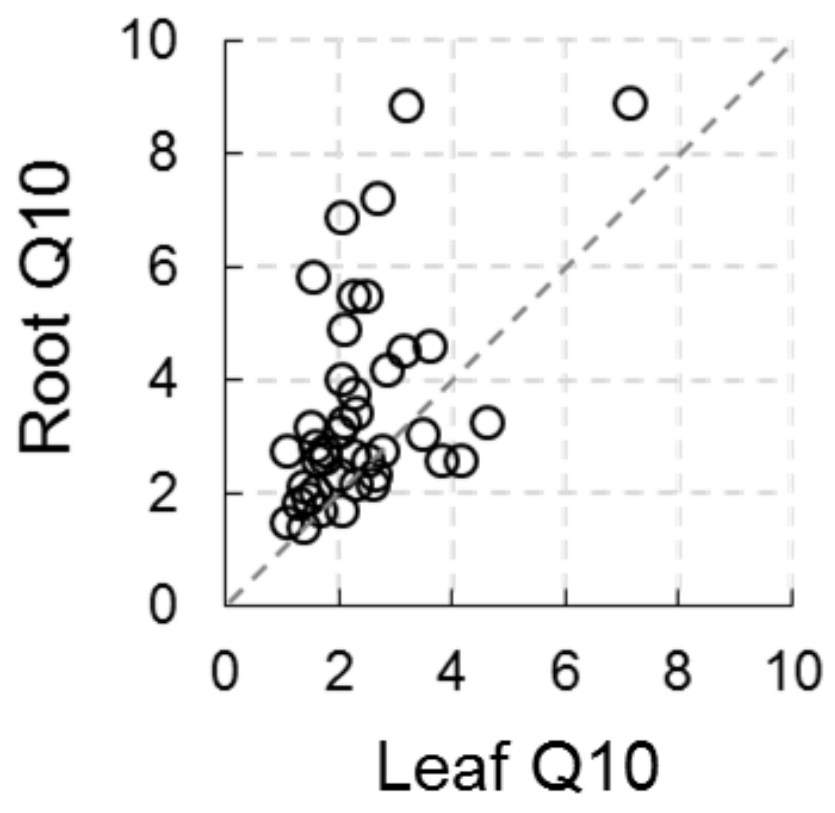

(D)

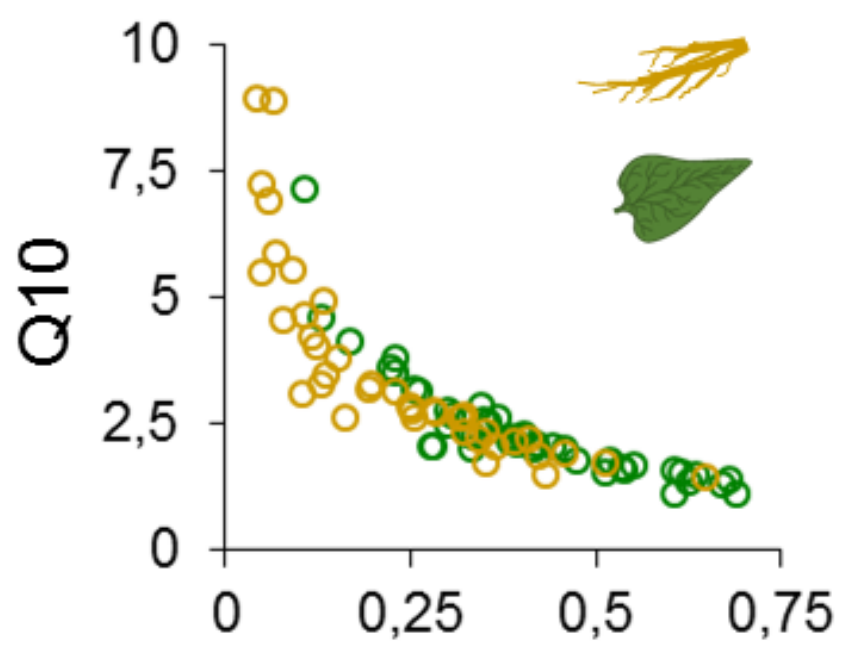

Litter decay rate - $K$

\section{Figure 5}

Moreover, Q10 was higher for fine root than the corresponding leaf litter in 35 out of 43 cases $(81.40 \%)$ (Figure 5b). For leaf litter, Q10 was positively correlated with $\mathrm{N}$ content and negatively with lignin and lignin/N ratio (Figure 5c). Q10 of fine roots, instead, recorded only a highly significant negative correlation with lignin content. Finally, Q10 of both leaf litter and fine roots was negatively correlated with their decay rate 


\section{Supplementary Files}

This is a list of supplementary files associated with this preprint. Click to download.

- 1SupplementaryMaterial.docx 